\title{
The Study of Anatomy and Fiber Banana Leaf as a Potensial Wrapping
}

\author{
Nunung Harijati*, Rodliyati Azrianingsih, Eva Affanti Prawaningtyas \\ Biology Department, Faculty Science, Brawijaya University, Malang, Indonesia. \\ Email: harijati@ub.ac.id
}

Received May $1^{\text {st }}, 2013$; revised June $1^{\text {st }}, 2013$; accepted June $18^{\text {th }}, 2013$

Copyright (C) 2013 N. Harijati et al. This is an open access article distributed under the Creative Commons Attribution License, which permits unrestricted use, distribution, and reproduction in any medium, provided the original work is properly cited.

\begin{abstract}
The aims of this research were to study the leaf anatomy of Musa brachycarpa, M. Paradisiacal normalis, M. sapientum and $M$. cavendishi as well as the length, width, and thickness of the leaf and the number, diameter, and tensile strength of leaf fibers. Samples were collected in Dampit, Wajak and Batu, Malang. Indonesia. The criteria for leaf samples were that they were fresh, mature, and not torn. Microscope slides used for anatomical observations were prepared using a semi-permanent method. The Retting method was applied to extract the fibers, and fiber strength was measured using a tensile strength tester. One way Anova and the Duncan test were used to establish the mean and other parameters of the dependent variables (length-, width-, thick-leaf; number-, diameter-, and tensile strength of fiber). The T-test (independent sample) was used to determine the mean diameter of fiber in adaxial and abaxial sites. The results showed that $M$. Brachycarpa had the highest number of fiber cells, a wider diameter fiber, and more adaxial fiber cells than the abaxial site. The diameter of fibers was $5-6 \mu \mathrm{m}$. M. sapietum had the longest and widest leaves and leaf thickness was highest in M. Paradisiaca. The tensile strength values ranged from $35 \times 10^{-4}-48 \times 10^{-4} \mathrm{MPa}$. The tensile strength of the observed species did not differ significantly.
\end{abstract}

Keywords: M. brachycarpa; Number of Fibers; Diameter of Fibers; Strength of Fiber

\section{Introduction}

Food wrapping or packaging using plastic or styrofoam is increasing from year to year and may threaten health unwittingly. The ingredients of the material that composes plastic or styrofoam such as polystyrene, polyvinyl chloride, and acrylonitrile can act as a carcinogenic agents $[1,2]$. Especially acrylonitrile may act as a genotoxic agent by inducing DNA strand breakage and sex chromosome non-disjunction in spermatogenesis [3]. The plastic or Styrofoam tempts consumers and foodsellers because it offers a convenient method to contain or wrap food. To avoid such hazardous effects of plastic or styrofoam, traditional local method already used leaves as a food wrapping or packaging or containers. In Indonesia, the most popular leaf for food wrapping is the banana leaf. The reasons for this preference include the low cost and ease of obtaining banana leaves, their large width and their property of not transferring pigments or colour to wrapped food. Sometimes teak leaves are used instead of banana leaves. However, teak leaves are not as

\footnotetext{
Corresponding author.
}

popular because they have a rough texture surface and transfer a red color to food. Traditional cakes that use banana leaf as wrapping included "Nagasari", "mendut", "lemper", and "lemet". And "Pepes", "Gadon", and "Bothok" are traditional cuisines that also use leaves as wrapping. Even porridge rice frequently used banana leaf as container. Stories told from one generation to another mention that not all types of banana produce leaves suitable for wrapping; only leaves from a few species can be used. M. branchyacarpa is regarded as the best species for providing wrapping. The leaf of this species does not easily tear, is flexible and easy to fold and can be stapled using thin bamboo slivers. Others types of banana leaf may be used with additional treatment. These include the leaves of M. parasidiaca and M. sapietum. A hypothesis proposed here is that leaf flexibility for folding is supported by certain anatomical and structural characteristics, including the tensile strength of fibers. In this study we compared anatomical and structural characterisctics of $M$. branchycarpa, $M$. parasidiaca, $M$. sapietum and $M$. cavendishi. Musa cavendishi was not common as wrapping so it can function as reference or control. 


\section{Materials and Methods}

\subsection{Leaf Sample Preparation}

Banana (M. branchycarpa, M. parasidiaca, M. sapietum and $M$. cavendishi) leaves were obtained from Malang district including Dampit (Musa Sapientum-"PisangRajamala"), Wajak (M. brachycarpa-"Pisangklutuk"), and the administrative town, Batu (M. Paradisiaca normalis-"PisangKepok"; M. Cavendishi-"Pisang Caven - dish"). Leaves were sampled from mature banana that had not yet produced fruitand not torn. Each species was taken from different group, with each group functioning as a replicate. Each leaf collected was measured forlength, width, and thickness.

\subsection{Slide Preparation and Anatomy Observation}

Leaf-anatomy slides were prepared using a semi-permanent method. First, 5 pieces of $10 \times 5 \mathrm{~mm}^{2}$ were cut from the widest section of the leaf blade. Each piece was cut using a clamp on hand microtome sampling at least 3 slices. All slices were fixed in FAA fixative for 1 minute then washed three times with distilled water for 1 minute. Following washing, the slices were stained with $1 \%$ safranin (in distiled water) for 1 minute, followed by washing three times, each time for one minute. The slice was then placed on a glass slide, a drop of glycerin was applied, a cover glass placed on the preparation, which was sealed using transparent nail polish. Now the slide was ready for observation from the adaxial to abaxial side and the diameter and number of fiber cells could be deter- mined. Images were recorded using digital camera.

\subsection{Fiber Extraction and Measuring Fiber Strength}

The first step of fiber extraction was retting. i.e. leaves were submerged in water, with 2 tea spoon of soil to enhance the decomposition of non-fibrous material. This treatment was considered to be sufficiently advanced when the epidermis began to peel off. The second and third steps were scuthingand hackling respectively [4]. Fiber strength was determined using atensile strength tester (Imada, Japan) according to the SOP of Manufacture's equipment.

\subsection{Data Analysis}

The null hypothesis that there was no difference in length, width, and thickness of M. brachyacarpa, M. parasidiaca, M. sapetum, M. cavendishi was tested as well as the number, diameter, and strength of fibers; ANOVA test was applied usingSPSS 17.0 for Windows. When the result was significant, a Duncan post hoc was conducted. T-independent test was used to establish whether the number of fibers in the adaxial and abaxial part of the leaf-differed.

\section{Result and Discussion}

In general banana leaf anatomy consisted of the adaxial epidermis, hypodermis, palisade layer, spongy layer, bundle sheat cell, abaxial epidermis, laticifer [5,6]. Laticiper is a cell or cell group or vessel that contains latex or sap cells [7]. Among the banana species observed, only M. branchyacarpa (Klutuk) and M. sapietum (Rajamala) had lacticifer cell (Figures 1(a) and (c)). The cells were located scattered in palisade layer and in association with vascular bundles. The location lacticifer in palisade layer and cell in vascular bundles is in line with Sumardi and Wulandari results [6]. However lacticifer of Heliconia sp only occur in bundle cells [5]. Our result contrast with Sacchetti et al. results [8], since in Sacchetti et al. [8] the lacticifer cell located in abaxial site just below epidermis.

Adaxial and abaxial epidermis of four banana leaves were shown to consist of simple and small size cells with convex outer cell in all the banana species (Figure 1). A hypodermis only occured at adaxial site. It had two to three layer cells, where as the cell layer beneath the epidermis had a smaller size than two other layers in $M$. branchyacarpa, M. sapietum, M. cavendish (Figures 1(a), (c) and (d)). Two hypodermal layers only were found in M. parasidiaca (Figure 1(b)). The occurrence of 2 - 3 layer hypodermal cells in these bananas is typical of the Musaceae family. In contrast with Musa sp., leaves of Heliconia sp which are same order as Musaceae, only have one hypodermal layer [4]. Two size groups of vascular bundle were observed, large and small. They occurred in between mesophyll cells. Hypodermal cells above the larger vascular bundle had two layers with reduced size cells and both ends of the vascular bundle were capped with sclerenchyma fiber (Figures 1(a)-(d)). Sometimes hypodermal cell above small vascular bundle of M. parasidiaca was fan shaped. (Figure 1(b)). Each vascular bundle was wrapped with parenchyma bundle sheath cell. Mesophyll composed of palisade and spongy tissue. The palisade consisted of two (Figures 1(a) and (c)) to three layer cells (Figures 1(b) and (d)), and spongy tissue was formed from irregular shapecells, which fused together produced a large aerenchyma (Figure 1(b)). The aerenchyma was located between two vascular bundles.

Traditional wisdom and practice using leave from one generation to another reveal that $M$. Branchyacarpa (PisangKlutuk) are the most popular and acceptable as food wrapping material, followed by $M$. parasidiaca (PisangKepok) and M. sapietum (PisangRajamala). This wisdom is supported by results of length and thickness measurements of M. Branchyacarpa and M. parasidiaca which were not significantly different (Figures 2(a) and (c)). M. sapietum was wider and longer (Figures 2(a) and (b)) the three others species. M. cavendishi was 


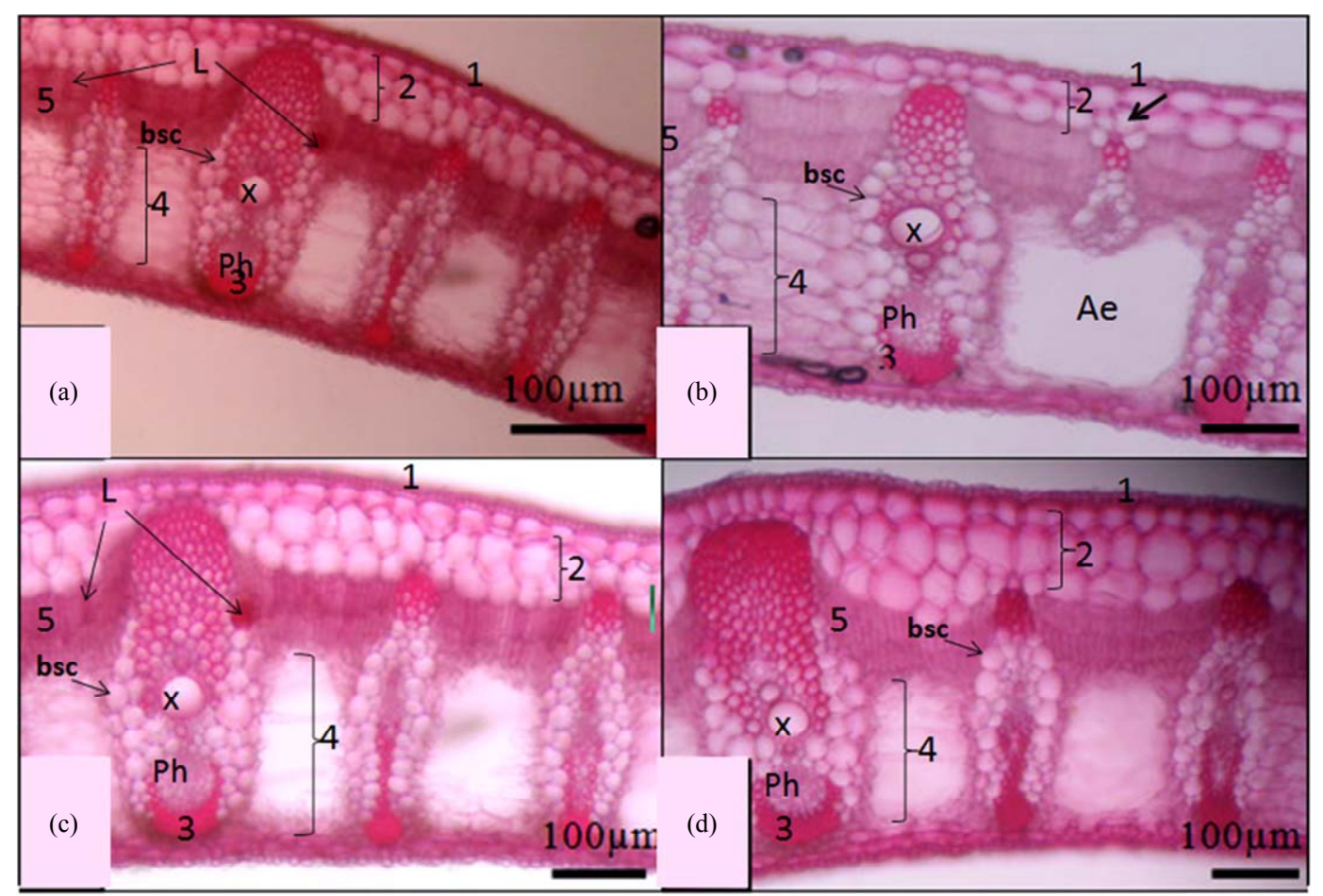

Figure 1. Cross section of banana leaves in (a) Musa branchyacarpa ("PisangKlutuk"), (b) M. parasidiaca ("PisangKepok”), (c) M. sapietum ("PisangRajamala”), (d) M. cavendishi ("Pisang Cavendish”).

shown to be short, narrow, and thin (Figures 2(a)-(c)), therefore $M$. cavendishi's leaf was the last choice or preference as a wrapping.

The preference of $M$. Branchyacarpa leaves for wrapping food was supported by internal analysis i.e. the determination of fiber number and fiber diameter. $M$. Branchyacarpa had the highest number of fibers, significantly different than three other species (Figure 3(a)) and a higher fiber diameter (Figure 3(c)). The number and fiber diameter of $M$. Branchyacarpa were 274 fiber cell and $5.97 \mu \mathrm{m}$ in diameter respectively. On the other hand $M$. cavendishi had the lowest fiber number and a lower fiber diameter i.e. 68 fiber cell and $5.08 \mu \mathrm{m}$ in diameter. The overall range of fiber diameter of the leave between $5-6 \mu \mathrm{m}$ was lower than fiber diameter in pseudo stems of banana. Because of those fiber diameters no issue leaf fiber involved industry. The diameter of banana pseudo-stem was shown to be at least $15 \mu \mathrm{m}$ and has potential as material for greaseproof paper [9]. However, tensile strength of fiber was not different statistically between species (Figure 4). The tensile strength of tested banana species had a value ranging between $0.35-0.48 \mathrm{~N} / \mathrm{cm}^{2}$ or $35 \times 10^{-4}-48 \times 10^{-4} \mathrm{MPa}$ whereas $1 \mathrm{~N} / \mathrm{cm}^{2}=0.01 \mathrm{MPa}[10]$. These values are very low if compared with tensile strength of Jute (393 MPa) or pine apple $(170 \mathrm{MPa})$ [11]. Therefore based on tensile strength value, banana leave was not suitable for industry purpose. Banana leaves were suitable for food wrapping or disposable plate [12]. These findings indicate that flexibility leaves as wrapper was more influenced by number and diameter of fiber than fiber tensile strength.

People used to use the adaxial site as a hinge or a folding site during wrapping action. This behavioris explained by the results which indicated that $M$. Brachycarpa had more fibers in the adaxial than abaxial site; this was statistically different according t-test independent sample. On the other hand following the t-test the other species showed no difference for adaxial and abaxial sites (Figure 3(b)). Additionally, the fiber diameter in adaxial and abaxial site had asimilar size (Figure 3(d)).

\section{Conclusion}

M. branchyacarpa has three layers of hypodermal cells, two layers of palisade cells, and both adaxial and abaxial fibres capping vessel bundles. The species also has a greater number and wider fiber diameter. In contrast with M. branchyacarpa, $M$. cavendishi had the fewest fibers and the narrowest fiber diameter. The number and diameter size of fibers tended to be higher in the adaxial site than the abaxial site, especially in M. branchyacarpa. The tensile strength of all tested species was not significantly different, but $M$. sapietum tended to be higher. In addition to tensile strength, $M$. sapietum also had longer and wider leaves. Based on the traditional practice of using M. branchyacarpa as food wrapping it is the 


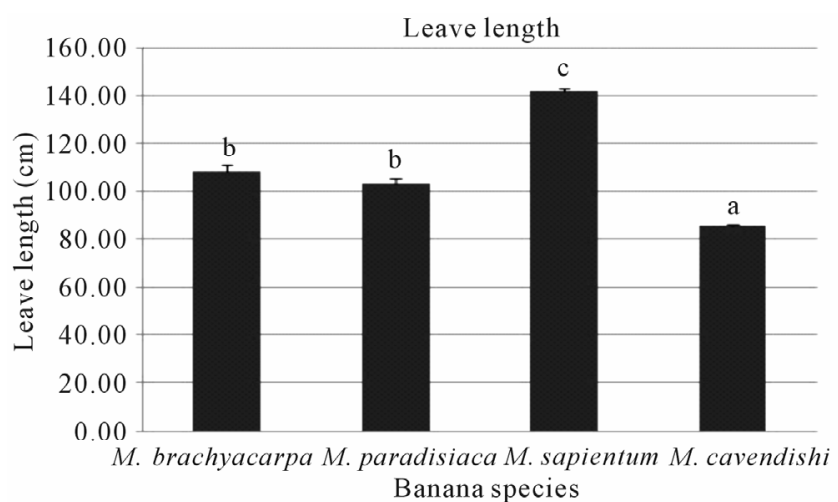

(a)

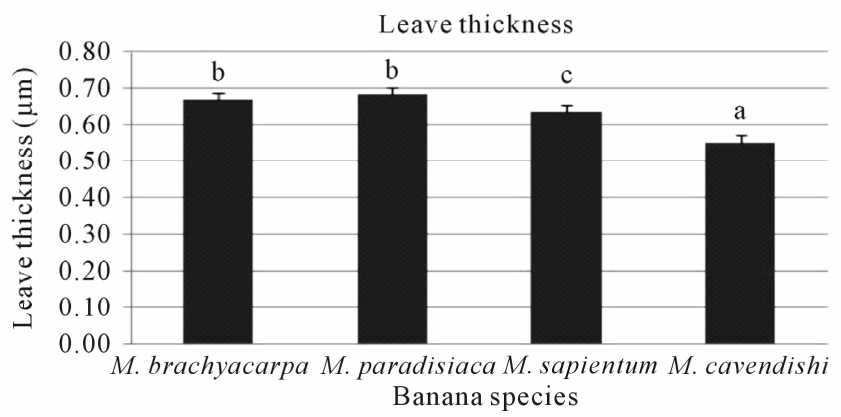

(c)

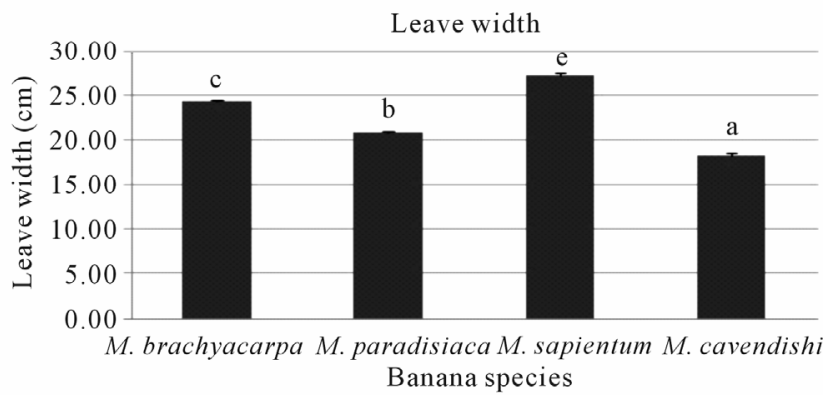

(b)

Figure 2. Measurement length, width, and thickness of $M$. brachycarpa, M. paradisiaca, M. sapientum, and M. cavendishi. Note: bars with same notation are not significantly different by theDuncan 0.05 test

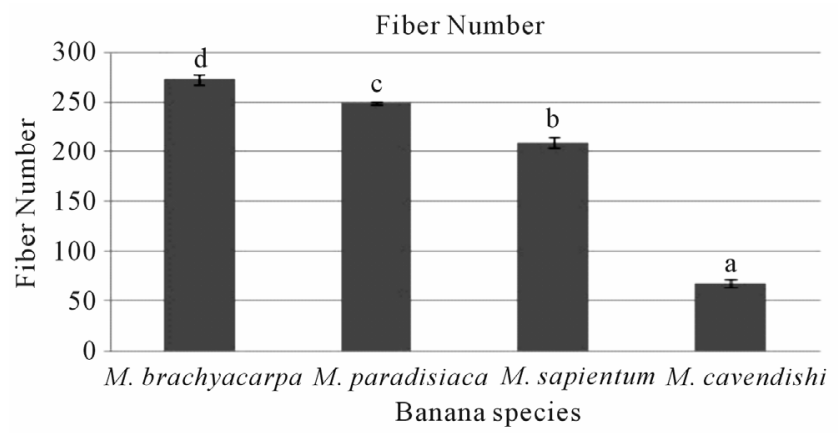

(a)

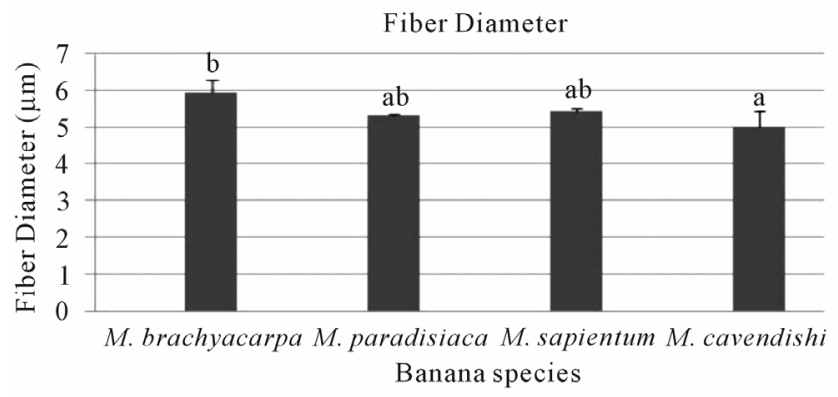

(c)

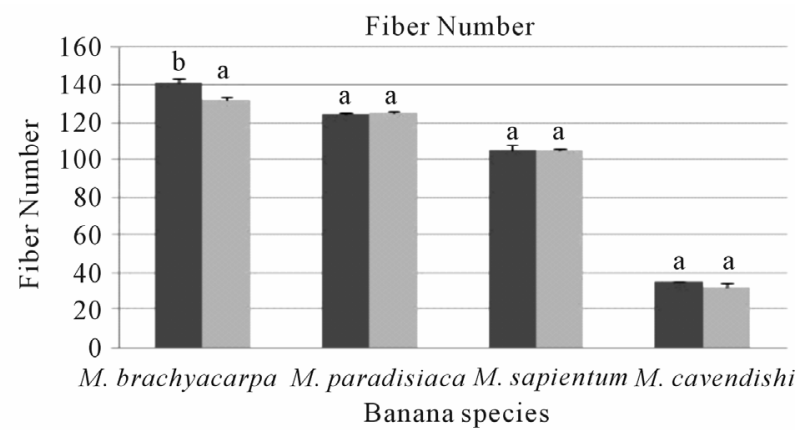

(b) adaxial abaxial

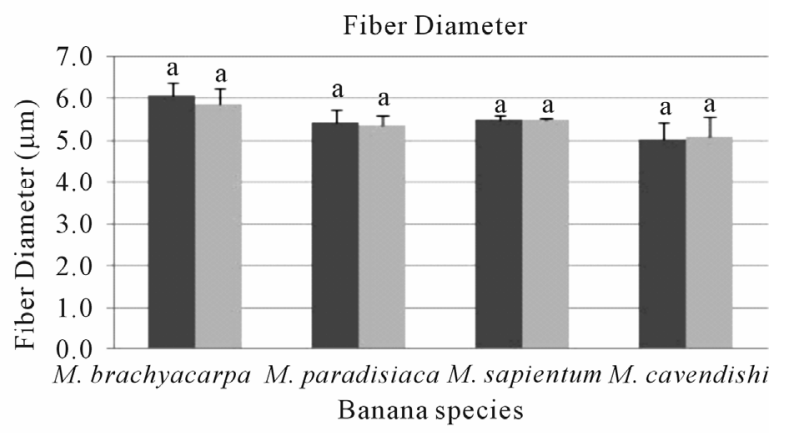

(d)

Figure 3. Fiber number and fiber diameter of M. brachycarpa, M. paradisiaca, M. sapientum, and M. cavendishi. Note: same notation that followed species showed not significantly different in Duncan $\boldsymbol{\alpha} \mathbf{0 . 0 5}$ test (a), (c) same notation that followed each species showed not significantly different in t-test independent sample (b), (d). 


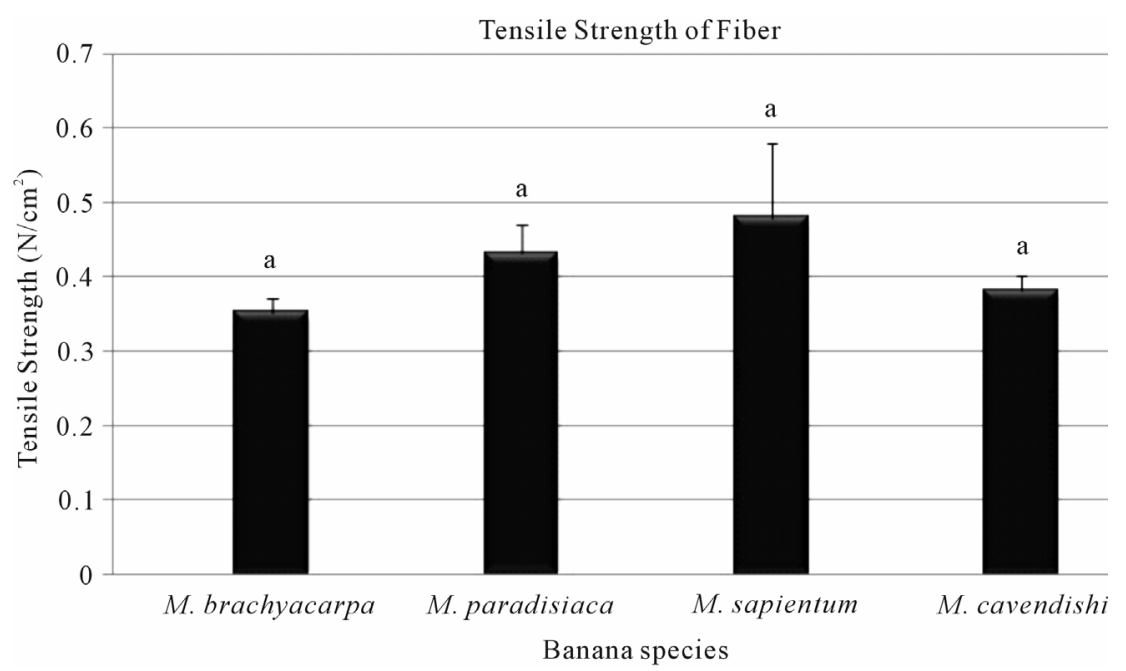

Figure 4. Fiber's tensile strength of M. brachycarpa, M. paradisiaca, M. sapientum, and M. cavendishi. Note: same notation that followed species showed not significantly different in Duncan $\alpha 0.05$ test.

most reliable as food and cuisine wrapping. This is supported by its wider leaf width and the higher number of fibers in the adaxial site. These should be criteria to look for in other species or varieties of banana as potential wrapping.

\section{REFERENCES}

[1] D. Coggon and P. Cole, "Acrylonitrile and Human Cancer-An Overview," Scandinavian Journal of Work, Environment \& Health, Vol. 24, Suppl. 2, 1998, pp. 81-82.

[2] A. A. Hidayat, "Bahaya Kemasan Plastik," 2011. http://www.pantonanews.com/berita-119-bahaya-kemasa n-plastik-.html

[3] D. X. Xu, Q. X. Zhu, L. K. Zheng, L. K. Wang, H. M. Shen, L. X. Deng and C. N. Ong, "Exposure to Acrylonitrile Induced DNA Strand Breakage and Sex Chromosome Aneuploidy in Human," Mutation Research/Genetic Toxicology and Environmental Mutagenesis, Vol. 534, No. 1, 2003, pp. 93-100. doi:10.1016/S1383-5718(03)00055-X

[4] Ortega, "Materials: Cloth, Wood, and Paper," 2005. http://www.natharim.com

[5] J. K. Triplett and B. K. Kirchoff,'Lamina Architecture and Anatomy in the Heliconiaceae and Musaceae (Zingiberales)," Canadian Journal of Botany, Vol. 69, No. 4, 1991, pp. 887-900. doi:10.1139/b91-115
[6] I. Sumardi and M. Wulandari, "Anatomy and Morphology Character of Five Indonesian Banana Cultivars (Musa spp.) of Different Ploidy Level," Biodiversitas, Vol. 11, 2010, pp. 167-175.

[7] C. B. Beck, "An Introduction to Plant Structure and Development," Cambridge University Press, Cambridge, 2010.

[8] G. Sacchetti, M. Ballero, M. Serafini, C. Romagnoli, A. Bruni and F. Poli, "Laticifer Tissue Distribution and Alkaloid Location in Vincasardoa (STEARN) PIGN. (Apocynaceae), an Endemic Plant of Sardinia (Italy)," Phyton (Horn, Austria), Vol. 39, 1999, pp. 265-275.

[9] T. Goswami, D. Kalita and P. G. Rao, "Grease Paper from Banana (Musa parasidiaca L.) Pulp Fibre," Indian Journal of Chemical Technology, Vol. 15, 2008, pp. 457461.

[10] T. Guimares and B. Chris, "Thermal Expansion of Kevlar 49 Yarns," 2003. www-civ.eng.cam.ac.uk/cjb/papers/cp46.pdf

[11] D. N. Saheb and J. P. Jog, "Natural Fiber Polymer Composites: A Review," Advances in Polymer Technology, Vol. 18, No. 4, 1999, pp. 351-363. doi:10.1002/(SICI)1098-2329(199924)18:4<351::AID-A DV6>3.0.CO;2-X

[12] S. Sharrock, "Use of Musa," INIBAP Annual Report, 1996. 